\title{
Does democracy need sovereignty?
}

\author{
Article
}

Accepted Version

Tansey, O. (2011) Does democracy need sovereignty? Review of International Studies, 37 (4). 1515 -1536. ISSN 0260-2105 doi: https://doi.org/10.1017/S0260210510001087 Available at https://centaur.reading.ac.uk/20815/

It is advisable to refer to the publisher's version if you intend to cite from the work. See Guidance on citing.

To link to this article DOI: http://dx.doi.org/10.1017/S0260210510001087

Publisher: Cambridge University Press

All outputs in CentAUR are protected by Intellectual Property Rights law, including copyright law. Copyright and IPR is retained by the creators or other copyright holders. Terms and conditions for use of this material are defined in the End User Agreement.

\section{www.reading.ac.uk/centaur}

\section{CentAUR}

Central Archive at the University of Reading

Reading's research outputs online 


\title{
Does democracy need sovereignty?
}

\author{
OISÍN TANSEY*
}

\begin{abstract}
Non-state entities that aspire to statehood are increasingly developing democratic norms and practices, in part to enhance their claims for independence. However, the prospects for democracy in cases of 'problematic sovereignty' are little understood. This article seeks to explore the important but under-explored relationship between sovereignty and democracy, and in particular to assess the extent to which sovereignty is, or is not, a prerequisite for democracy. The article advances two arguments. First, it argues that there is no clear-cut relationship between sovereignty and democracy, as sovereignty is a complex concept that is comprised of several important, and distinct, constituent elements. Second, the article argues that the legal recognition of statehood (international legal sovereignty) is of marginal importance in this area, and should not be seen as a necessary condition for democratic rule. The article examines the process of democratic transition in the non-state entity of Somaliland to provide empirical support.
\end{abstract}

Oisín Tansey is Lecturer in International Relations at the Department for Politics and International Relations at the University of Reading. He is the author of Regime-Building Democratization and International Administration (Oxford University Press, 2009). Oisín can be contacted at: \{o.tansey@reading.ac.uk\}.

The recognition of Kosovo's independence in February 2008 created a divide in the international community and reignited debates about the balance to be struck between the rights to self-determination and the sanctity of territorial integrity. For some, Kosovo's declaration of independence represented an unjustifiable breach of Serbian sovereignty and a precedent that could lead to wider international instability. For others, the event represented an opportunity to settle one of the final disputes stemming from the break-up of Yugoslavia and reward the perseverance and commitment of Kosovo's majority ethnic Albanian population in the face of a legacy of Serb domination. A key element of Kosovo's claim to independence, and the international support it received, was its rhetorical and practical support for democracy and multi-ethnicity. It sought to justify its independence claim not just on the basis of traditional factors such as its effective control over a defined territory and permanent population, ${ }^{1}$ but also on the basis

\footnotetext{
* The author would like to thank Christopher Bickerton, David Chandler and Kirsten Ainley for their helpful comments on earlier versions of this article.

${ }^{1}$ Traditionally, recognition of new states has been conditional on a number of factual conditions. These are that the aspiring state must demonstrate a defined territory, a permanent population, an effective government and the capacity to enter into relations with other states. See, Sean D. Murphy 'Democratic Legitimacy and the Recognition of States and Governments', The International and Comparative Law Quarterly, 48:3. (July 1999), pp. 545-81.
} 
of its commitment to human rights and its record of democratic development. ${ }^{2}$ Kosovo's experience is reflective of a wider shift among aspiring states, which increasingly refer to their democratic legitimacy as a core element of their right to statehood. Many other non-state entities that seek recognition, such as Abkhazia and Nagorno-Karabakh in the Caucasus and Somaliland in the Horn of Africa, appeal to the international community's normative commitment to democracy when promoting their own cases for independence. The extent to which this shift in approach is effective, however, is a matter of debate. While some argue that democratic progress in these aspiring states increases the likelihood of international support, ${ }^{3}$ others suggest these appeals are most likely to fall on deaf ears and have limited effect on the chances of international recognition. ${ }^{4}$ Recent practice certainly suggests that these democratic appeals have not been matched by a substantial change in international policy; there is still an overwhelming bias against secession and few non-state actors have translated their democratic developments into an increase in international support.

Nonetheless, these changes of legitimation strategy have raised questions about the wider relationship between sovereignty and democracy, and have challenged some pre-existing assumptions concerning the nature of democratic rule. Democracy has generally been viewed as the preserve of sovereign states, and the potential for democratic development in non-state entities has been underexplored. Yet the recent developments in these non-state settings challenge some traditional views and pose new questions. Can non-state entities actually become democratic? Is democracy possible without sovereignty? This article seeks to address these issues and explore the relationship between democracy and sovereignty in greater depth. In particular, it challenges some pre-existing assumptions and, using conceptual and empirical arguments, asserts that sovereignty should not be viewed as a prerequisite for democracy. Conceptually, sovereignty entails a set of separate political elements that each have varying implications for political authority and the possibilities for democratic rule at the domestic level - some aspects of sovereignty are crucial for democracy, while others may be of little relevance. In particular, I argue that the international recognition of sovereign statehood should not be viewed as a requisite for democracy, as it does not affect the political realities of authority relations at the domestic level - the forms of accountability and representation that are required for democratic rule can exist with or without legally recognised sovereignty. Empirical variation in sovereignty among political units also raises questions over any proposed clear-cut relationship between sovereignty and democracy, as some political entities that exhibit 'problematic sovereignty' ${ }^{5}$ - that is, those political authority arrangements that deviate in some way from the conventional understanding of the sovereign state - also exhibit evidence of democratic development. Several non-state entities have shown evidence of significant democratic development in recent years, and this article

${ }^{2}$ Kosovo's declaration of independence makes several references to democracy and begins with the words, 'We, the democratically-elected leaders of our people [...].' See Assembly of Kosovo, 'Kosovo Declaration of Independence', Pristina (17 February 2008).

3 Anne-Marie Gardner, 'Beyond standards before status: democratic governance and non-state actors', Review of International Studies, 34 (2008), pp. 531-52.

${ }^{4}$ Nina Caspersen, 'Separatism and Democracy in the Caucasus', Survival, 50:4 (2008), pp. 113-36.

${ }^{5}$ Stephen Krasner (ed.), Problematic Sovereignty: Contested Rules and Political Possibilities (New York: Columbia University Press, 2001). 
focuses in particular on the case of Somaliland, which lacks recognition of its declared sovereignty but has nonetheless developed a robust, although not flawless, democratic regime.

However, the article does not advance the argument that sovereignty is unimportant for democracy, or that democracy can easily flourish in contexts of problematic sovereignty. On the contrary, while international recognition may not be a requisite for democratic rule, its absence may be an indicator of other more challenging sovereignty-related issues. Domestic autonomy and freedom from external intervention represent aspects of sovereignty that are fundamentally important for democracy, and their absence represents a much more serious impediment to democratic rule. The closer a political entity resembles a fully sovereign state, the greater the prospects for democracy. But lack of international recognition alone is no barrier to democratic progress.

The following sections explore these arguments in greater detail, exploring the conceptual aspects of the relationship between sovereignty and democracy in the early sections before turning to an empirical exploration of democratic development in non-state entities and Somaliland in particular.

\section{Conventional understandings of sovereignty and democracy}

Sovereignty and democracy are two of the most fundamental concepts that exist in contemporary political science, but their relationship to one another has been comparatively under-explored. Democracy has been addressed most extensively in the comparative politics literature, and has generally been discussed in relation to established states in the international system - sovereignty has been taken as given rather than incorporated into the analysis. There is a widespread but tacit assumption that sovereign statehood is a necessary condition for democracy, and there is thus limited work that explores the nature of or potential for democratic government outside the existing state structure.

Similarly, treatments of sovereignty in the International Relations literature have tended not to dwell on the nature of the domestic regime structures in sovereign states, and are more concerned with the meaning of sovereignty itself and its implications for international rather than domestic politics. Sovereignty is not generally assumed to entail a particular type of political regime at the domestic level, and thus for many there is no inherent relationship between sovereignty and democracy. States can be fully democratic or be fully authoritarian, and still retain their sovereign status regardless. As A. A. Stein suggests, the relationship between sovereignty and democracy is unproblematic, even unquestioned - there is no reason to believe that sovereign states are hostile to democracy, or that democracy is hostile to sovereign statehood. ${ }^{6}$ The main exception to this strand in the IR literature is the writing on globalisation, and the incentives and possibilities it creates for democracy at a supranational level. ${ }^{7}$ Here the debate concerns the

\footnotetext{
${ }^{6}$ A. A. Stein, 'The Great Trilemma: Are Globalization, Democracy, and Sovereignty Compatible?', unpublished manuscript (2002).

${ }^{7}$ Ibid., and see Daniele Archibugi, David Held and Martin Köhler (eds), Re-Imagining Political Community: Studies In Cosmopolitan Democracy (Polity Press and Blackwell Publishers, 1998).
} 
impact of globalisation on sovereignty and thus the consequent potential for state-level democracy - those who argue that sovereignty is eroded by globalisation also posit that democracy becomes harder to achieve, and thus suggest (implicitly or explicitly) that state sovereignty is in some way a prerequisite for democracy.

One of the clearest propositions that advances this argument that democracy requires sovereignty can be found in the work of Linz and Stepan, who make the explicit argument that official statehood is a 'prerequisite to democracy', and that the challenges of achieving democracy cannot be overcome 'unless the territorial entity is recognized as a sovereign state'. ${ }^{8}$ This argument rests on the reasoning that democracy as a political regime type requires the features of a modern sovereign state, not least a central state administration that can raise taxes, provide public services in response to the electorate, and maintain a monopoly on the legitimate use of force. Although rarely acknowledged explicitly, to a great extent this view is taken for granted in the wider literature on democracy and democratisation, which tends to focus on democracy and other regime types in recognised states only.

Yet this approach to thinking about the implications that sovereignty has for democracy tends to ignore the experience of many non-state entities that in recent years have embarked on processes of democratic development, in part to strengthen their claims for independence. It also rests on a traditional view of sovereignty as a fixed and indivisible feature of international politics, one that is either present or absent. However, recent research has raised questions over the utility of this approach to conceptualising sovereignty, and has suggested that sovereignty should be seen as a multi-faceted and divisible concept. If this latter approach is pursued, and if sovereignty as a concept is unbundled and its constituent attributes are viewed separately, the relationship between sovereignty and democracy becomes much less clear-cut. Suggesting that one is a prerequisite for the other becomes a difficult statement to make. The following section examines this shift in approach to sovereignty, and highlights its usefulness for understanding the full complexity of the relationship between sovereignty and democracy.

\section{Shifting perspectives on sovereignty}

The treatment of sovereignty within IR scholarship has shifted significantly over recent decades, moving away from an earlier, classical perspective that treated sovereignty as an indivisible and fixed element of the international state system towards a plurality of contemporary approaches, some of which have sought to problematise sovereignty and identify its changing nature and multiple attributes.

A classic definition of sovereignty comes from Hinsley, who identifies sovereignty as 'the idea that there is a final and absolute political authority in the political community [...] and no final and absolute authority exists elsewhere'.

${ }^{8}$ Juan J. Linz and Alfred Stepan, Problems of Democratic Transition and Consolidation: Southern Europe, South America and Post-Communist Europe (The Johns Hopkins University Press, 1996), p. 18.

9 Francis H. Hinsley, Sovereignty, second edition (Cambridge: Cambridge University Press, 1986), p. 26. 
This idea of final authority is often further associated with the notions of internal and external sovereignty. Internal sovereignty refers to authority of the state at the domestic level, and suggests that there is no higher authority at the domestic level than the state itself. External sovereignty refers to relations at the international level, and in particular to the absence of any higher authority than the sovereign state on the international stage, which implies in turn the independence of states from outside intervention. The classical perspective on sovereignty is also firmly linked to the idea of the sovereign state, and assumes that sovereignty is a fixed and exogenous attribute of states, so that a state is either sovereign, or it is not a state. $^{10}$

The argument that sovereignty is an indivisible feature of international politics is supported by the reasoning that, while sovereignty may be constituted by multiple attributes, each of them is so crucial that all of them have to be present for sovereignty to exist, and if any one of them is absent, sovereignty is absent also. For example, sovereignty is frequently associated with a bundle of attributes, including territory, population, autonomy, and authority, ${ }^{11}$ and the classical approach to sovereignty requires that each of these be present together in order for sovereignty to exist.

At a broader conceptual level, this involves thinking about sovereignty as a 'bounded whole' - a concept that designates a certain entity that by its nature requires a dichotomous approach. These concepts are both mutually exclusive and mutually exhaustive: mutually exclusive in that both cannot exist at the same time, and mutually exhaustive in that both are the only two options that exist. ${ }^{12}$ For example, a person can be dead or alive, not in between. Similarly, a political entity can be sovereign or not sovereignty - there is no middle ground. With bounded wholes, the central idea is that each attribute only reflects the concept in question as long as all the others are present. ${ }^{13}$ Thus, the classical perspective holds that any political entity that lacks a core element of sovereignty should not be viewed as a sovereign state - the absence of one element of sovereignty undermines the meaningfulness of any other elements that might exist. ${ }^{14}$

However, some recent scholarship on sovereignty has challenged the classical perspective, pointing to the changing nature of sovereignty over time and highlighting the importance of the constitutive elements of sovereignty as distinct from sovereignty as an indivisible concept. David Lake points to two shifts in recent treatments of the concept, those relating to constructivist treatments of sovereignty, and to issues of 'problematic sovereignty'. For constructivists, classical conceptions of sovereignty are problematic in the manner in which they treat sovereignty as a given, as a fixed element of the international system. Instead, constructivists see sovereignty as endogenous rather than exogenous to the international system, and argue that it is a social fact that is constructed and

${ }^{10}$ David A. Lake, 'Reflection, Evaluation, Integration: The New Sovereignty in International Relations', International Studies Review, 5:3 (September 2003), pp. 303-23.

${ }^{11}$ Dominik Zaum, The Sovereignty Paradox: The Norms and Politics of International Statebuilding (Oxford University Press, 2007), p. 3.

12 Giovanni Sartori, The Theory of Democracy Revisited (Chatham, NJ: Chatham House, 1987).

13 David Collier and Robert Adcock, 'Democracy and Dichotomies: A Pragmatic Approach to Choices about Concepts', Annual Review Political Science, 2 (1999), pp. 537-65.

${ }^{14}$ For more on the notion of indivisibility in the classical perspective on sovereignty, see David A. Lake, Hierarchy in International Relations (Cornell University Press, 2009), chap. 4. 
reproduced over time by the practices of states themselves. Consequently, sovereignty is not a fixed element of international politics, but can change due to the changing behaviour and expectations of states. ${ }^{15}$

More importantly for this article, the second shift from the classical approach has involved a move away from the conception of sovereignty as an indivisible element of international politics, and a greater recognition of the deviations from the conventional political arrangement of the sovereign state. ${ }^{16}$ This move is perhaps most closely associated with the work of Stephen Krasner, who has shown how sovereignty has multiple elements rather than existing as an inviolable whole, and has demonstrated how some of its most important constituent parts are often compromised in the practice of international politics. In particular, Krasner distinguishes between four different elements of sovereignty, those of:

- international legal sovereignty, which refers to the mutual recognition of independent statehood by other states in the international system

- domestic sovereignty, which refers to the structure and effectiveness of state institutions

- Westphalian sovereignty, which refers to the absence of external influence and penetration in domestic affairs - essentially the freedom from foreign intervention

- interdependence sovereignty, which refers to the capacity of state authorities to regulate cross-border flows.

Krasner's most significant contribution has been to demonstrate that these elements do not necessarily go together, and that the historical record clearly shows that states have routinely violated elements of each other's sovereignty, especially Westphalian sovereignty. Far from being indivisible, Krasner argues persuasively that sovereignty is not only divisible in conceptual terms, but is frequently split apart in the cut and thrust of international politics.

This approach of disaggregating sovereignty into multiple categories brings with it a number of advantages to political analysis. ${ }^{17}$ First, viewing a concept like sovereignty in disaggregated terms simply better reflects reality, as it takes into account cases of problematic sovereignty and thus gives a better picture of what the world actually looks like. Second, and following from the first, pursuing disaggregation means that it is possible to develop more fine-grained theories about the role of sovereignty in politics, and what implications it has for political outcomes either at the domestic or international level. If a dichotomy is used, much of the detail is lost and theories might give misleading impressions of the role of sovereignty. ${ }^{18} \mathrm{~A}$ final advantage of this approach is that it also enables a more

${ }^{15}$ See for example, Christian Reus-Smit, 'Human Rights and the Social Construction of Sovereignty', Review of International Studies, 27:4 (2001), pp. 519-38.

${ }^{16}$ Lake, 'Reflection, Evaluation, Integration: The New Sovereignty in International Relations'; James A. Caporaso, 'Changes in the Westphalian Order: Territory, Public Authority and Sovereignty', International Studies Review, 2:2 (2000), pp. 1-28; Robert O. Keohane, 'Political Authority After Intervention: Gradations in Sovereignty', in J. L Holxgrefe and Robert O. Keohane, Humanitarian Intervention: Ethical, Legal, and Political Dilemmas (Cambridge University Press, 2003).

${ }^{17}$ For a fuller discussion of the advantages and disadvantages of conceptual disaggregation, see Collier and Adcock, 'Democracy and Dichotomies: A Pragmatic Approach to Choices about Concepts'.

18 Barabara Geddes, Paradigms and Sandcastles: Theory Building and Research Design in Comparative Politics (University of Michigan Press, 2003), p. 43. 
nuanced appreciation of sovereignty's relationship with other aspects of domestic and international politics. In particular, by examining sovereignty's constituent elements, rather than taking the concept as a bounded whole, it becomes possible to see that different elements of sovereignty have different implications for the potential for democratic rule. The relationship between sovereignty and democracy is not clear-cut, but rather depends on the extent to which sovereignty is fully, or only partially, present.

\section{Sovereignty and democracy}

Before proceeding to examine how different sovereignty arrangements might affect the prospects for democracy, it is first important to examine the nature of democracy itself. Like sovereignty, democracy is in many ways an essentially contested concept, ${ }^{19}$ but one recent four-part definition touches on its most significant features. According to Levitsky and Way, democracy requires four political attributes, those of: free and fair competitive elections, full adult suffrage, a full range of political freedoms, and importantly, government autonomy from outside influence. ${ }^{20}$ Working with this four-part definition, it becomes possible to explore how different sovereignty arrangements might be more or less suited to providing a foundation for democratic rule. This section examines each of Krasner's four elements of sovereignty in turn, and assesses their respective relationships with democracy and their effect on the possibilities for democratic rule. The analysis suggests that while some elements of sovereignty are indeed critical for democracy, others are less relevant and have few implications for democracy by virtue of their presence of absence.

The first aspect of sovereignty to address is that of international legal sovereignty', the recognition of sovereignty by other states within the international system. In many ways, recognition is tacitly viewed within political science scholarship as a requirement for democratic rule, and some argue this position explicitly. The argument by Linz and Stepan outlined above, for example, posits that democracy will not be achievable 'unless the territorial entity is recognised as a sovereign state'. ${ }^{21}$ And as suggested, this view is supported tacitly in the literature on democracy and democratisation, which devotes attention to regime change processes almost exclusively in recognised states. Yet as will be discussed further below, this view is problematic as it leaves unstated what exactly it is that recognition contributes to democratic rule itself. In contrast, the argument advanced here suggests that international recognition of statehood is primarily declaratory, and has no actual impact on the nature of political government at the domestic level.

The second dimension of sovereignty is that of domestic sovereignty, referring to a state's ability to determine its own political system and structures. This is

${ }^{19}$ W. B. Gallie, 'Essentially Contested Concepts', Proceedings of the Aristotelian Society, N. S., 56, 1956, pp. 167-98.

${ }^{20}$ Steven Levitsky and Lucan A. Way, 'The Rise of Competitive Authoritarianism', Journal of Democracy, 13:2 (2002), pp. 51-65.

21 Juan J. Linz and Alfred Stepan, Problems of Democratic Transition and Consolidation: Southern Europe, South America and Post-Communist Europe (The Johns Hopkins University Press, 1996), p. 18, emphasis added. 
profoundly more important for the prospects of democratic rule than international recognition, as it is essential for democracy that the state has the resources and presence within a territory to assert its own authority and jurisdiction over domestic affairs. In this context, the importance of domestic sovereignty for democracy relates to the ability, and willingness, of the state to uphold and enforce political rights and the rule of law throughout a territory. The notion of domestic sovereignty is close to that of state capacity, which in the comparative politics literature has been identified as a critical element of democratic rule. ${ }^{22}$ The presence and authority of the state ultimately affects the extent to which democratic rights and freedoms can be both enforced and protected throughout the territory. ${ }^{23}$

The third aspect of sovereignty is Westphalian sovereignty, which relates to the idea of freedom from external interference in domestic structures and decisionmaking. Westphalian sovereignty is inextricably linked to the norm of nonintervention, which suggests that states must respect each other's internal politics and their right to determine their own domestic affairs. As such, Westphalian sovereignty has clear importance for the prospects for democratic rule, as domestic autonomy is one of the key attributes of democracy outlined above. If domestic actors do not have final authority within the boundaries of the political system, and decisions and outcomes are determined by external actors, the channels of representation and accountability required for democracy break down. If Westphalian sovereignty is breached, so too, is democracy.

The final dimension of sovereignty is that of interdependence sovereignty, which relates to the level of control a state can exercise over cross-border flows. The extent to which this type of sovereignty has been eroded is a major subject of debate within the globalisation literature, entailing divergent views on the extent to which globalisation is having a negative impact on the prospects for democracy at the level of the nation state. For some, such as David Held, globalisation is creating a series of disjunctures between the ideal and actual role of the state in determining domestic affairs, as the real location of authority seeps beyond state boundaries. One of these disjunctures is that between the claim to formal authority over border control by individual states, and an actual absence of such control in practical terms. Consequently, globalisation reduces interdependence sovereignty (as well as domestic sovereignty) and contributes to a democratic deficit within the state - if a state cannot control its own borders, then domestic politics comes under the influence of processes and actors that cannot be constrained through conventional electoral means at the national level. ${ }^{24}$ Interdependence sovereignty thus also has implications for democracy.

As can be seen, then, each of these dimensions of sovereignty is distinct from the other, and each has particular implications for the nature and prospects of democratic rule. In certain circumstances, where states are well established and where political authority is located firmly with the central government, all the core

22 Guillermo O'Donnell, 'On the State, Democratization, and Some Conceptual Problems: A Latin American view with Glances at Some Postcommunist Countries', in Guillermo O'Donnell (ed.), Counterpoints: Selected Essays on Authoritarianism and Democratization (Notre Dame, IN: University of Notre Dame Press, 1999), pp. 135-7.

${ }^{23}$ Francisco E. Gonzalez and Desmond King, 'The State and Democratization: The US in Comparative Perspective', British Journal of Political Science, 34 (2004), p. 193.

24 David Held, Models of Democracy (Polity Press, 2006), p. 294. 
elements of sovereignty may be present, and together will be sufficient to support democratic rule. $^{25}$ In cases where some elements of sovereignty are absent, however, democratic politics may be difficult to achieve or maintain throughout the territory in question.

I thus argue that it is not possible to make broad statements about the relationship between sovereignty and democracy in general terms, because different elements of sovereignty have different implications for the possibilities of democratic government. Rather, it is necessary to disaggregate sovereignty, identify its constituent elements, and examine how each of these is related to regime type in general, and democracy in particular. Once this is done, it becomes clear that different elements of sovereignty have different implications for democratic rule, and that while some should be viewed as prerequisites for democracy; others have little or no impact on whether democracy can or cannot be achieved. In particular, it appears that international legal sovereignty is significantly less important than other elements of sovereignty, and may not be necessary in order for democracy to be attained.

While this position is clearly indebted to Stephan Krasner's work on sovereignty and the benefits of disaggregation, it is on this point that the analysis departs somewhat with his own writings on democracy and sovereignty. Krasner has recently suggested that democracy can be promoted in difficult settings by a breach of Westphalian sovereignty through 'shared sovereignty' arrangements. This form of international engagement requires international legal sovereignty among all parties, but envisages international involvement in the domestic affairs of a target states on a permanent basis in order to ensure stability and promote democracy. ${ }^{26}$ The emphasis of this article, however, is that Westphalian sovereignty is more important than international legal sovereignty for achieving democracy, and goes beyond Krasner's writings to suggest that democracy can be achieved even where international legal sovereignty is absent.

The remainder of the article explores the relationship between sovereignty and democracy further, and examines in particular the potential for democracy outside the established system of recognised sovereign states. Problematic sovereignty raises many questions over the capacity of political entities to engage in a full range of domestic and international activities, but it may not necessarily eliminate the possibilities for democratisation and democracy.

\section{Democracy without statehood: adapting the declaratory/constitutive debate}

A central question concerning the possibility for democracy in contexts of problematic sovereignty concerns the extent to which recognised statehood itself is in some way a necessary pre-condition for democratic rule. I have suggested above that recognition need not be seen as a necessary condition, as it does not in itself

\footnotetext{
${ }^{25}$ It should be noted, however, that the full range of sovereignty attributes will not be sufficient to bring democracy about, but only to support it if it is established by domestic actors. Democratisation requires political agency as well as structures of sovereignty.

${ }^{26}$ Stephen D. Krasner, 'The Case for Shared Sovereignty', Journal of Democracy, 16:1 (2005), pp. $69-83$.
} 
influence political authority arrangements at the domestic level, so does not directly contribute to democracy itself. This argument rests in part on a line of reasoning that is advanced in a particular approach to state recognition that exists in international law. In legal scholarship, a debate already exists concerning the role that recognition of statehood plays in the process of state creation, involving a divide between those who argue that recognition simply involves acknowledging that a political entity has met the criteria of statehood (the declaratory approach), and those who argue that recognition is much more than an acknowledgement of statehood, but is rather itself a central element in the formation of a state (the constitutive approach). While this debate is primarily concerned with the implications of recognition for the nature of state creation, it can be adapted in order to explore the particular implications of state recognition for the nature of the political regime.

The central issue of contention in this debate concerns the role of recognition of aspiring new states by already existing states in the international system. In the declaratory school, recognition is not a requirement for the establishment of a state, and rather represents a statement by the international community acknowledging that an entity has achieved statehood. Recognition in itself does not contribute to the formation of the state, but instead simply acknowledges it has come into being. ${ }^{27}$ Consequently, the declaratory approach suggests that existing states have limited scope for exercising discretion in the recognition of statehood - if an entity has met the criteria of statehood, recognition should follow. If such an entity is denied recognition, this is not because it lacks any element of statehood, but because existing states have not followed the principles of international law.

The constitutive approach on the other hand, suggests that recognition is much more than a formality, is in no way automatic, and is central in the establishment of the state itself. According to this doctrine, recognition itself is constitutive of new statehood in that it is viewed as a core element of it, so that a state only becomes a state through recognition. This is in part because the recognition of statehood by existing states confers new rights on the political entity in question, rights that are seen as a core element of statehood itself. These include the right to be viewed as an international legal personality of equal standing with other states in the international system, which in turn paves the way for a range of privileges on the international stage. ${ }^{28}$ As Murphy suggests, it is through international recognition that 'the State can lawfully request military support from other States; can lawfully refuse entry to foreign military forces; can lawfully negotiate and conclude international agreements; can avail itself of other rights accorded sovereigns under international law and vindicate those rights before available international forums; and can demand respect by other States for sovereign acts exercised within its territory, including the enactment and enforcement of civil and criminal laws. ${ }^{29}$ For those in the constitutive camp, without

27 Thomas D Grant, The Recognition of States: Law and Practice in Debate and Evolution (London: Praeger, 2000), Introduction. See also James Crawford, The Creation of States in International Law (Oxford: Oxford University Press, 2006).

${ }^{28}$ Christian Hillgruber, 'The Admission of New States to the International Community', European Journal of International Law, 9:3 (1998), pp. 491-509.

${ }^{29}$ Sean D. Murphy, 'Democratic Legitimacy and the Recognition of States and Governments', International and Comparative Law Quarterly, 48 (1999), pp. 545-6. 
recognition and the rights it entails, a political entity simply lacks essential features of statehood.

This debate has largely taken place within the international law discipline and has revolved mainly around the implications of international recognition for the politics of state creation. Yet these two approaches can also be applied to the question of whether recognition has implications for the nature of the political regime, and in particular, whether recognition of statehood is in some way a precondition of democracy. As discussed, the contention of this article is that democracy can emerge even in the absence of international legal sovereignty, and the declaratory position provides support for this assertion. As recognition of statehood from this perspective involves simply an acknowledgement of an already existing set of relations, and in and of itself adds nothing substantively new to a political entity, then lack of recognition should not in principle be seen as an obstacle to the development of democracy. An entity can develop the conditions of statehood and can also introduce the institutions of a democratic political regime, and recognition by other states only acknowledges the status of existing political arrangements. Democracy is a political system that rests on domestic state-society relations, involving accountability and representation, which require some elements of sovereignty (for example, government capacity and freedom from external interference) but can exist independently of international recognition.

The constitutive position, on the other hand, suggests an alternative conclusion, in which lack of international recognition might have significant consequences for the potential for democracy. As from this perspective the act of recognition itself confers important rights and thus in a significant way constitutes the state, then the absence of these rights and core elements of statehood would raise questions over the extent to which a political entity could meet the challenges of guaranteeing democratic rule. For example, without the rights under international law to enter into official channels of international diplomacy with other states, or to have legal protection from external intervention, a non-state entity could be constrained in the extent to which is can act on behalf of, or protect, its citizens.

However, while the lack of legal statehood does clearly place limits on political entities, a number of considerations suggest it does not in itself preclude the possibilities for democratic rule. First, it can be argued that recognition is not actually crucial to achieving the kind of state rights that it is often associated with. For example, unrecognised Taiwan has developed innovative arrangements that allow it to engage in international diplomacy and engage with established states almost as if it too were a state. While Taiwan has no official relations with the US, it has extensive unofficial relations and both countries have embassy-like offices in their respective capitals. Also, some have advanced the concept of 'pre-state rights', which aspiring states achieve once they attain a sufficient level of political control over a given territory. ${ }^{30}$

Second, it is also questionable that the kind of international rights that recognition does confer are actually necessary for democracy to be achieved. Democracy is essentially a particular type of relationship between a government and its people, and while international isolation resulting from non-recognition might restrict the ability of that government to gain the benefits that come with

\footnotetext{
${ }^{30}$ Marc Weller, 'The Self-Determination Trap', Ethnopolitics, 4:1 (2005), pp. 3-28.
} 
economic and political International Relations with foreign powers, it would not necessarily breach the channels of accountability and representativeness that are central to democratic rule.

Finally, while lack of recognition makes a non-state entity more vulnerable to the types of violations that would otherwise be protected under international law, such as external intervention, history clearly shows that such rights are not sacrosanct, and that even when enjoyed by established states, are frequently broken. ${ }^{31}$ The legal force of recognition, in essence, may not have significant political implications on the ground.

Consequently, the lack of international sovereignty itself should not be seen as a barrier to democratic development, and it is rather the lack of other elements of sovereignty, especially Westphalian and domestic sovereignty, that pose more of a threat. The following section examines more closely the prospects for democratic rule in specific contexts of problematic sovereignty, and highlights in particular the potential for, and restrictions on, political democracy in the context of unrecognised entities.

\section{Non-state entities, democracy, and sovereignty}

One of the most interesting aspects of contemporary politics that has been under-explored in the IR literature is the existence of distinct and often very autonomous political systems outside the international state system. So-called de facto states lack international recognition of statehood, but nonetheless entail an organised political leadership that has achieved sufficient capacity to provide governmental services to a given population in a defined territorial area. ${ }^{32}$ Some contemporary examples of de facto states include Northern Cyprus, which declared independence in 1983 but has only been recognised by Turkey, and Somaliland in Somalia, which declared independence in 1991 and has yet to be recognised by any established state. Most de facto states have either declared independence or aspire to independent statehood, and many also profess to have embarked on a process of democratisation.

While de facto states would not appear to be promising environments for democratic government, the analysis above suggests they should not be ruled out purely on the basis of the lack of international recognition of their independent status. Indeed, arguably the most prominent de facto state is Taiwan, which lacks recognition of independent statehood but is nonetheless a stable and consolidated territorially-bound political system. Instructively, Taiwan has also undergone a process of democratic transition and is now also a stable democracy, even despite the lack of recognised statehood. ${ }^{33}$ Taiwan's international status remains a point of contention, and China has long threatened to invade if the island declares formal independence. But the lack of international legal sovereignty has not in itself posed a serious obstacle to democratic transition and consolidation.

\footnotetext{
${ }^{31}$ This is a central thesis of Krasner, Sovereignty: Organized Hypocrisy.

${ }^{32}$ Scott Pegg, International Society and the de facto State (Aldershot: Ashgate 1998).

33 Joseph Wong, 'Deepening Democracy in Taiwan', Pacific Affairs, 76 (2003).
} 
Another case of democratic practices existing in a de facto state can be found in Somaliland, which is legally part of Somalia but has fought for independence since the early 1960s and declared independence since 1991. It has a stable government, a multi-party system and has held successive rounds of competitive elections. Its nascent political regime is not without problems, but it has made significant strides on the road to democracy in the absence of legal sovereignty. ${ }^{34}$

Yet while these cases show democratic potential without sovereignty, they should not lead to the conclusion that de facto states present an entirely unproblematic environment for democracy, as it is also the case that the absence of legal sovereignty is likely to be an indicator of more severe and challenging sovereignty-related problems. One frequent problem is that many de facto states have only weak institutional structures and lack the kind of autonomy and capacity that is necessary to support democratic government - that is, there is an absence of domestic sovereignty. ${ }^{35}$ Similarly, in most cases where de facto states have developed, the entity in question is legally part of a larger state from which it is striving to secede, often with problematic results. The 'host state' will often resist the secessionist efforts of the de facto state and the dispute will pose significant obstacles for democratic development. ${ }^{36}$ Where host states are sufficiently powerful, they will be in a position to intervene in entity politics in de facto states in ways that undermine local autonomy, and thus violate both Westphalian and domestic sovereignty. For example, before and after Kosovo declared independence, Serbia has resisted its efforts and sponsored a wide range of Serb-run unofficial institutions inside Kosovo's borders that cater for Kosovo's minority Serb community. Such practices limit the authority of central government, and when domestic authorities do not have the autonomy to act independently of outside actors, representative politics becomes difficult to attain. ${ }^{37}$ These divisions also affect internal politics, as the populations in these entities are often divided on the issue of independence. Such internal societal divisions present further obstacles to successful democratisation as they limit the potential for the kind of mutual engagement and compromise that are necessary for democratic politics. ${ }^{38}$

With de facto states, breaches of autonomy can also come from other international sources, and especially neighbouring states that share similar cultures, histories or ethnic ties. These neighbouring states often act as sponsors for de facto states, supporting their claims for independence and providing diplomatic assistance. While this form of involvement can be positive for democratic development, it can also entail a level of financial and even military support that renders de facto state governments little more than puppet regimes that are entirely dependent on

${ }^{34}$ International Crisis Group, Africa Report N0 66, 'Somaliland: Democratisation and Its Discontents' (28 July 2003).

${ }^{35}$ For a discussion of weaknesses and deficiencies in non-state entities, see Pål Kolstø, 'The Sustainability and Future of Unrecognized Quasi-States', Journal of Peace Research, 43:6 (2006), pp. 725-6.

${ }^{36}$ Charles King 'The Benefits of Ethnic War: Understanding Eurasia's Unrecognized States', World Politics, 53:4 (2001).

${ }^{37}$ Oisín Tansey, 'Kosovo: Independence and Tutelage', Journal of Democracy, 20:2 (April 2009).

${ }^{38}$ For more on the implications of societal divisions on the potential for democracy, see the discussion of 'stateness' problems in Linz and Stepan, Problems of Democratic Transition and Consolidation, chap. 2 . 
outside sponsorship. ${ }^{39}$ Two clear examples are the cases of Abkhazia and South Ossetia in Georgia, which became the source of violent conflict between Russia and Georgia in August 2008, and which Russia subsequently recognised as independent states while stationing its own troops within the territories. ${ }^{40}$ In such cases, where governing authorities do not enjoy autonomy from sustained outside intervention by powerful sponsors, the prospects of democratic transition without a significant shift in power relations are highly limited.

These settings thus provide significant challenges for democratic development, and weak institutions and interfering neighbours can pose significant problems. Yet the lack of international recognition of statehood in these contexts does not itself pose a major obstacle, and significant democratic developments have taken place without it. The relationship between sovereignty and democracy is thus a complex one, and cannot be reduced to clear-cut statements that one is a prerequisite for the other. Sovereignty has many attributes, and it is the combination of these in a political entity that determines its suitability for a given political regime. Problematic sovereignty settings do not make for an easy home for democracy, but neither are they totally unable to support it. The remainder of the article examines one contemporary de facto state, that of Somaliland, which has a significant record of democratisation without international recognition. Although a single case cannot be used to suggest a broader pattern, analysis of Somaliland does highlight the potential for democracy without legal sovereignty, while also pointing to the extra challenges that problematic sovereignty entails for democratic development.

\section{Democracy without sovereignty: Somaliland}

One of the clearest examples of a political entity existing in state-like form but without international recognition of statehood is that of Somaliland. Officially a region in the state of Somalia, since 1991 Somaliland has sought recognition of independent status from the international community and has increasingly developed a separate identity and political structure from that of Somalia. Furthermore, the political structures that have been developed have in recent years been undergoing a process of liberalisation, so that the nascent political regime that exists in Somaliland has significant democratic characteristics, even despite its lack of international recognition. ${ }^{41}$

The roots of the Somaliland's current separatist stance can be traced to the legacy of European colonialism in the region. From the late nineteenth century, the Horn of Africa became the target of European colonial expansion, and Britain and Italy both competed for control of the territory. Britain established the Somaliland Protectorate, while the neighbouring territory of Somalia to the south was administrated by Italy. In 1960, when Italy and Britain granted independence to

39 Nina Caspersen, 'Separatism and Democracy in the Caucasus', Survival, 50:4 (2008), pp. 113-36.

${ }^{40}$ See Roy Allison, 'Russia Resurgent? Moscow's Campaign to "coerce Georgia to peace", International Affairs, 84:6 (2008), pp. 1145-71.

${ }^{41}$ Mark Bradbury, Adan Yusuf Abokor and Haroon Ahmed Yusuf, 'Somaliland: Choosing Politics over Violence', Review of African Political Economy, 30:97 (2003), pp. 455-78. 
Somalia and Somaliland respectively, the two new independent states quickly agreed to unify and the new, enlarged Somali state emerged. ${ }^{42}$ However, the new union quickly faltered, and the ideal of Somali unification was undermined by the reality of inter-regional differences and tensions. These differences were exacerbated by the military regime of General Mohamed Siyaad Barre, which came to power after a 1969 coup and, through its policies of repression and perceived discrimination against the north, prompted the rise of a resistance movement in the former British colony, the Somali National Movement (SNM). After the Barre regime was overthrown and the Somali state essentially collapsed in 1991, the SNM unilaterally withdrew from the 1960 union with Italian Somalia and declared independence for the northern territory of Somaliland.

Since 1991, Somaliland has consolidated its separatist position, and has developed the structures of autonomous self-government within its declared borders, including administrative, security and justice systems. ${ }^{43}$ At the same time, the entity has appealed to the international community for recognition, and has focused in particular on achieving membership of the African Union. Somaliland rests its claim on the argument that the union of 1960 had failed and that Somaliland is returning to the position of independent statehood it briefly held after the British withdrawal. It therefore defines its territory according to the borders of the British Somaliland Protectorate and argues that as a former colony it has the same right to self-determination enjoyed by the other colonial territories that achieved independence in the decades after World War II. However, while the African Union acknowledges that these factors make Somaliland's claim for independence 'unique', it has so far refused to grant recognition and no individual state has yet unilaterally recognised Somaliland. ${ }^{44}$

In recent years, Somaliland has also added a new element to its appeal for recognition - the idea that its claim to statehood is enhanced by the democratic nature of its political structures. This reflects recent changes in Somaliland that have seen a liberalisation of the political system and the development of a nascent democratic regime. ${ }^{45}$ During the 1990 s, Somaliland was ruled by a parliament of unelected clan representatives, but after 2001 it expanded political rights and embraced electoral politics. Problems with Somaliland's current political system remain, but it has nonetheless achieved more in terms of democratic development than have many other states that were once viewed as part of the 'third wave' of democratisation. ${ }^{46}$ Furthermore, and crucially, the obstacles that Somaliland does face in its efforts to achieve a fully democratic political system are not tied to its lack of international recognition, but rather relate instead to other more conventional domestic issues such as the qualified nature of elite commitment to a full range of democratic rights and freedoms.

42 David D. Laitin and Said S. Samatar, Somalia: Nation in Search of a State (Westview Press, Boulder, Colorado, 1987).

43 Bradbury et al., 'Somaliland: Choosing Politics over Violence'.

44 International Crisis Group, 'Somaliland: Democratisation and Its Discontents', p. i.

${ }^{45}$ Seth Kaplan, 'The Remarkable Story of Somaliland', Journal of Democracy, 19:3 (July 2008), pp. 143-58.

46 Samuel P. Huntington, The Third Wave: Democratization in the Twentieth Century (University of Oklahoma Press, 1991). 


\section{Somaliland's democratic development}

Somaliland's process of political transition has in many ways been ongoing since it declared independence in 1991, as its structures of government have undergone several rounds of reform, with each round introducing greater pluralism into the political system. After declaring independence, the SNM initially had sole control over the new political entity, but greater pluralism was introduced during the 1990s and Somaliland established a parliament that was structured according the beel system, which involved a proportionate distribution of government positions according to clan structures. A president of Somaliland was also appointed, and in 1993 Mohamed Haji Ibrahim Egal was selected for a five-year term. Further developments were made in the late 1990s when a new constitution was drafted that provided for direct multi-party elections for both the presidency and the lower house of parliament, as well as a provision that the constitution itself would have to be approved in a public referendum. ${ }^{47}$ These political reforms were coupled with a consolidation of the government's authority in Somaliland, as internal sources of inter-clan conflict were dealt with at successive national conferences and the institutions of state were further developed. Clan militias were demobilised and disarmed, and a new national army was created. Similarly, by the late 1990s most of the territory Somaliland claimed was under the firm control of the central government, whereas at times in the early 1990s it had extended little beyond the capital Hargeysa. ${ }^{48}$

The first major step in the direction of democracy came in 2001, when a referendum was held on the adoption of the recently finalised Somaliland constitution. The document declared the Republic of Somaliland to be a 'sovereign and independent country', and affirmed that its political system would be based on 'peace, cooperation, democracy and plurality of political parties'. It provided for a presidential system but with significant legislative authority, and the beel system was to be replaced with multi-party elections. ${ }^{49}$

As the constitution included a declaration of independence, the referendum in May 2001 was widely perceived by many to be an endorsement of Somaliland's independence, and a 97 per cent approval rating from over a million votes cast (estimated at 66 per cent of the eligible voters) clearly displayed the popular support for Somaliland's appeal for statehood. ${ }^{50}$ The most significant no votes came in the eastern Sool region, where there is greater ambivalence concerning Somaliland's independence project within some clans that have ties with the rest of Somalia. ${ }^{51}$ Although there were some problems with the referendum process as a result of limited resources and experience, international observers nonetheless found the vote to be broadly free and fair, and in accordance with internationally recognised elections procedures. ${ }^{52}$

\footnotetext{
47 Academy for Peace and Development, 'Consolidation and Decentralization of Institutions' (July 2002), available at: \{www.apd-somaliland.org\}.

${ }^{48}$ International Crisis Group, 'Somaliland: Democratisation and Its Discontents'.

49 The Constitution of the Republic of Somaliland (2005), available at: \{www.somalilandlaw.com\}.

${ }^{50}$ International Crisis Group, 'Somaliland: Democratisation and Its Discontents'.

${ }^{51}$ Initiative \& Referendum Institute, 'Final Report of the Initiative \& Referendum Institute's Election Monitoring Team' (July 2001).

52 Ibid.
} 
After the referendum, Somaliland's next step was to provide the multi-party government that the constitution promised, and in August 2001 political parties were legalised. Local elections were held in December 2002, and gave rise to a new party system in Somaliland. While party competition for the local elections was open, restrictions ensured that only the three winning parties would gain representation and be allowed to compete in further elections (these restrictions are discussed further below). The highest profile party in the election, and the one that topped the poll, was the Democratic United Peoples' Movement (UDUB), which was established by the sitting President Mohamed Egal and which presented itself as the natural party of government. UDUB topped the poll with just over 40 per cent, gaining more than twice the vote of its nearest rival, the Kulmiye party, which was established by a former chairman of the SNM, Ahmed Mohamed Mohamud Silanyo, and received 19 per cent. The third placed party was the Party of Justice and Democracy (UCID), which received 11 per cent of the vote. In the wake of the vote, the political associations that had failed to achieve a top-three result were forced to dissolve, and many of their members joined one of the three parties that had achieved recognition, in some cases also gaining government positions. $^{53}$

The next major step in Somaliland's democratisation process was the presidential election of 2003. Somaliland's long-standing President, Mohamed Egal, died in May 2002, and it was his replacement, Dahir Rayale Kahin, who contested the election as UDUB's candidate. Rayale Kahin was joined in the race by Kulmiye's leader, Mohamud Silanyo, and by Faisal Ali Farah Waraabe of UCID. The campaign was generally calm, although marked by some tensions that emerged after it was alleged that UDUB was misusing government funds to support its electoral campaign. Nonetheless, the vote itself was held peacefully and was deemed to be free and fair by international election observers. The most significant problem with the election was that when the results were announced, it was revealed that Rayale Kahin had won from Kulmiye's candidate Mohamud Silanyo by just 80 votes. Kulmiye initially refused to accept the result, and it was only after both parties took the dispute to the Supreme Court and the result was confirmed that Silanyo ultimately acknowledged defeat. Rayale Kahin was subsequently sworn into power as Somaliland's first elected president on 16 May 2003.

Parliamentary elections subsequently took place in October 2005 and, as with the presidential elections, the poll was deemed to be both free and fair - although there were technical problems and some reports of double voting, there were no serious irregularities or violent incidences, and the vote was genuinely competitive among the three parties. ${ }^{54}$ In a significant development, the results also showed that while the President's party UDUB had received the most votes and seats, it had failed to achieve a majority in the lower house. UDUB gained 33 seats, with Kulmiye winning 28 and UCID winning 21. As a result, Kulmiye and UCID were able to form a coalition in the lower house of the bicameral parliament and thus initiate a period of cohabitation in which Somaliland's president represented a party different from those which held the parliamentary majority. Although UDUB

53 NORDEM, 'Somaliland: Presidential Election 2003', NORDEM Report 08/2003.

54 NORDEM, 'Somaliland: Elections for the Lower House of Parliament, September 2005', NORDEM Report 03/2006. 
initially sought to frustrate this shift in power by attempting to close down parliamentary business, intervention by the upper house of clan elders ensured that a full-blown constitutional crisis was avoided. ${ }^{55}$

In recent years therefore, Somaliland has undergone a process of significant political change, and has not only entrenched its position as a stable political entity but has developed many of the central elements of a democratic political regime. Whereas politics in Somaliland was dominated by unelected clan representatives in the 1990s, the years after 2000 witnessed regular direct elections with full adult suffrage and genuine competition between political parties. Alteration in political power has already taken place and the government has demonstrated sufficient autonomy to both make and enforce binding decisions within its claimed territory. In many respects, it would seem clear that the lack of Somaliland's official recognition of statehood has not stood in the way of it achieving extensive democratic progress. Somaliland further entrenched its nascent democratic system in June 2010, when after long delays a second presidential election was held. This time, the results of the 2003 election were reversed and Ahmed Mohamud Silanyo of the Kulmiye party won nearly 50 per cent of the votes to defeat sitting President Dahir Riyale Kahin.

However, in many important respects Somaliland's transition remains incomplete, and there are some quite significant barriers in the way of democratic consolidation. One of the most important obstacles to further democratic development is the constitutional provision that stipulates that no more than three political parties can achieve official registration. ${ }^{56}$ The eligible political parties were determined by the performance of political party associations in the 2002 local elections, with the three most popular associations gaining official party status. There are no mechanisms in place to allow for the registration of new parties or the de-registration of the existing three parties, meaning that the party system has essentially been frozen since the 2002 local elections. The limitation on the number of parties is the result of a concern that a proliferation of parties could lead to a fragmented and clan-based political system that might lead to the kind of instability and collapse seen in Somalia, ${ }^{57}$ but the restriction clearly breaches principles of political freedom, especially freedom of association, and it has led to some of the most problematic aspects of Somaliland's political transition. The restrictive and illiberal implications of this law were further demonstrated in 2007 when efforts were made to establish a new party called Qaran; its party leaders were quickly arrested, and it was only after considerable protest that they were released some months later. ${ }^{58}$

Other problems also represent obstacles to democracy in Somaliland. The constitution stipulates that only Muslims can gain representation in parliament, meaning that political competition is restricted along religious grounds and that not all citizens have equal political rights. Corruption within the government is also

55 Ibrahim Hashi Jama, 'The Sheikh Concordat - Settling Constitutional Disputes in the Somaliland Way?', Somaliland Focus (December 2006).

56 The Constitution of the Republic of Somaliland, Article 9.

57 Ibrahim Hashi Jama, 'Somaliland Electoral Laws', Somaliland Law Series 2009, available at: $\{$ www.somalilandlaw.com $\}$.

${ }^{58}$ See The Somaliland Times. 'Imprisoned political leaders to be released as elections approach', Issue 292 (2007), available at: \{www.somalilandtimes.net\}. 
a major concern, and the UDUB party in particular has been repeatedly criticised for breaking election rules by using state funds for party purposes. ${ }^{59}$ There are also some serious restrictions on key civil and political freedoms. While the media sector in Somaliland is generally independent and vibrant, there have been several reports of government harassment of journalists, as well as government interference in political broadcasting. The print media is competitive, but the state controls the only radio station that is legally permitted to operate. ${ }^{60}$

Somaliland's contested status has also had some negative implications for its ability to extend government authority throughout the territory. Although Somaliland claims jurisdiction over the territory within the borders of the colonial British Somaliland Protectorate, the borders to the east are contested not only with Somalia proper (which in reality has remained too weak to have any coherent policy on Somaliland), but also with Puntland, a second breakaway entity in northern Somalia. Puntland does not aspire to independence, but rather to being a regional government within a federal Somalia once it regains full state capacity. In the meantime, Puntland has established a system of autonomous regional government and its security forces have clashed with those of Somaliland over the disputed Sool and Sanaag regions in eastern Somaliland. In political terms, this has had a negative effect on the democratisation process as voting has been unable to take place in some districts of Sool and Sanaag in recent elections because of the associated security risks. Security concerns also led to the postponement of scheduled presidential elections. ${ }^{61}$ Originally scheduled for mid-2008, Somaliland's second presidential poll was postponed despite protests from the opposition parties. Along with references to instability in Sool and Sanaag, was justified in part in the wake of a series of coordinated suicide bombing attacks within Somaliland in October 2008. These attacks, which targeted government and international offices, killed over 20 people and were blamed on Islamic extremists involved in a broader insurgency throughout Somalia that had previously had limited impact within Somaliland. ${ }^{62}$ In 2009, the continued postponement of the presidential elections came close to becoming a political crisis, but the political parties agreed a resolution in September 2009, ${ }^{63}$ and the elections were held successfully in June 2010.

\section{Sovereignty and democracy in Somaliland}

While Somaliland has thus made profound political progress in recent years, it still faces formidable challenges before it is likely to fully institutionalise democratic rule. Yet it is arguable that obstacles to democratic development in the entity are not related to its lack of international recognition, but rather to separate and distinct problems. Some of these are clearly sovereignty-related, seen most clearly

\footnotetext{
59 International Crisis Group, 'Somaliland: Democratisation and Its Discontents'.

${ }^{60}$ Academy for Peace and Development, 'A Vote for Peace: How Somaliland Successfully Hosted its First Parliamentary Elections in 35 Years' (September 2006).

${ }^{61}$ NORDEM, 'Somaliland: Elections for the Lower House of Parliament, September 2005'.

62 'Deadly car bombs hit Somaliland', BBC News (29 October 2008).

${ }^{63}$ See the website of the Somaliland National Electoral Commission, available at: $\{$ http://www. necsomaliland.net/facts/elections.php .
} 
in the limitations on the government's authority over its territory in the disputed eastern regions of Sool and Sanaag. Political tensions with Puntland over borders and the consequent limitations on central control over these territories clearly restrict the potential for consolidation of democracy. Yet while this is a sovereignty-related problem, it is one that has much more to do with domestic rather than international legal sovereignty. Overcoming this obstacle will not be achieved through international recognition; there are many recognised states that have limited control over pockets of their own territory (for example, Pakistan), but rather requires a broader set of political changes that will contribute to the development of domestic and Westphalian sovereignty and the reduction or elimination of the dispute with Puntland. International recognition of Somaliland's sovereignty might help, but it is more likely that more traditional strategies of diplomacy and negotiation between Somaliland and Puntland will be the key to any breakthrough.

Furthermore, the most significant obstacles to greater democratisation in Somaliland are not in any way related to its problematic sovereignty, and come from much more conventional sources. Issues of corruption and media interference are familiar problems not only in the region but in many transitional (and some established) democracies around the world. The restriction on political parties has its roots in the history of clan rivalry in Somaliland's and Somalia's history, and it will require a change in political outlook among the ruling elite to overcome this obstacle rather than a change in Somaliland's legal status. There are already signs that that there may be movement on this issue independently of any shift of international policy towards Somaliland with recent cooperation among the banned party Qaran and the then opposition Kulmiye party. ${ }^{64}$

While the lack of legal statehood does limit the extent to which Somaliland can engage with other states and with regional and international organisations, it has not prevented the development of democratic institutions at the domestic level and should not prevent the further deepening of democracy in the entity. The problems facing democracy in Somaliland have their roots in other sources, and events in the disputed territory strongly suggest that international legal sovereignty in and of itself is no prerequisite for the attainment of democratic rule.

\section{Conclusion}

A significant section of the world's population currently lives in disputed territories that have distinct and contested political regimes. These non-state entities demonstrate key features of conventional statehood and sovereignty, but lack international recognition and often suffer from serious weaknesses and divisions. Given the antipathy within the international community to any major challenge to the norm of territorial integrity, it is unlikely that there will be any significant shift in the status of these entities from de facto to de jure states in the near future. Nonetheless, processes of political development have been taking place in these settings, and they hold out the possibility that democracy may be developed

${ }^{64}$ Jama, 'Somaliland Electoral Laws', fn. 50. 
outside of the system of sovereign states. As a result, these settings raise questions about traditional understandings of the relationship between sovereignty and democracy, and this article has sought to explore that relationship in greater detail and identify some of the principal patterns involved.

The argument here is that problematic sovereignty is not itself a bar to democratic rule, and rather that it is the specific combination of sovereignty attributes that determines a political entity's democratic prospects. Sovereignty entails a bundle of political attributes that relate to the status, capacity and autonomy of political authority arrangements. When all such attributes are present, sovereign statehood is the result, and there are no inherent obstacles to democratic development. But the absence of key elements of sovereignty can alter the prospects for democracy in important, and sometimes unexpected, ways.

Democracy requires autonomous governments that have the authority to make binding decisions, and promote and protect human rights and political freedoms throughout the territory. If political entities lack domestic autonomy and are unable to prevent interference from outside agents (if they lack domestic and Westphalian sovereignty), then the prospects for democracy can be seriously undermined. Without the ability to enforce decisions throughout the territory and without the ability to prevent the decisions made by external actors, central authorities will be unable to protect political freedoms or maintain a democratic link with their citizens. Yet if a political entity lacks international recognition, and has failed to achieve membership of the international society of states, this in itself is no bar to democratic government. Domestic and Westphalian sovereignty can exist in the absence of international legal sovereignty, and thus democracy is not tied to official legal statehood. Taiwan is the clearest example of a non-state entity that lacks international legal sovereignty, and nonetheless has established a well-developed democracy. The analysis of Somaliland demonstrates that other de facto states have also developed democratic political structures, and in many ways mirror more conventional states that have undergone processes of democratic transition.

Democracy and sovereignty thus have no simple relationship. One is not a clear prerequisite of the other, and neither necessarily go together. Rather, it is only by unbundling the concept of sovereignty that we can identify the particular aspects of their relationship that are most important, as well as those that have little meaning. There is no question that there are elements of sovereignty that are of critical importance for democracy, and that should be viewed as necessary conditions for democratic rule. But it should be equally clear that some aspects of sovereignty, especially regarding legal sovereignty, are of much less relevance to the realities of political government and regime type. Democracy is essentially a particular type of relationship between a government and its people, and while international isolation resulting from non-recognition might restrict the ability of a government to gain the benefits that come with economic and political international relations with foreign powers, it does not necessarily breach the core channels of accountability and representativeness that are central to democratic rule.

Consequently, further research should be carried out to examine the full range of possible relationships between sovereignty and democracy, using insights from both international relations and comparative politics. Democracy and sovereignty 
are foundational concepts in contemporary political research, but there has been only limited focused analysis of their relationship. In particularly there is scope for exploring how settings of problematic sovereignty might influence existing conceptions of the role of democracy in international relations. Democracy is seen as intrinsically important within much of the international community, contributing not only to freedom and human rights at the domestic level but also potentially to peace among states at the international level. But these benefits are generally envisaged as emerging from democracy in the context of full sovereign statehood, and it is thus necessary to explore whether such domestic and international benefits accrue from democracy in more unconventional political settings. Exploring the full implications of problematic sovereignty for regime type is unlikely to overturn most established understandings of the role of democracy in international relations, but it might overturn some. 